\title{
Population Briefs, Vol. 12, no. 1
}

Population Council

Follow this and additional works at: https://knowledgecommons.popcouncil.org/ series_newsletters_popbriefs How does access to this work benefit you? Let us know!

\section{Recommended Citation}

Population Briefs 12(1): New York: Population Council, 2006. 


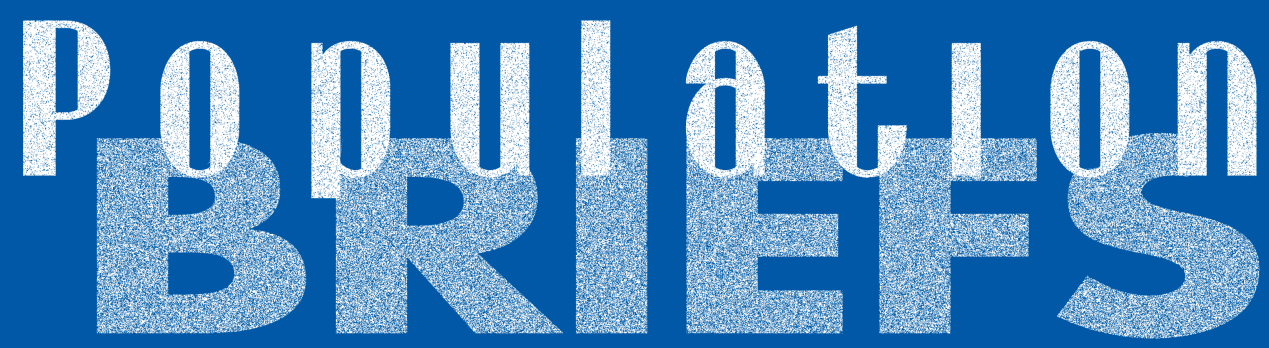

Reports on Population Council Research

\section{Unexplored Elements of Adolescence in the Developing World}

Adolescence entails changes, some of them drastic, in young people's bodies, emotions, capabilities, ways of thinking, and financial situations. Particularly for girls in the developing world, this period often fails to bring opportunities for increased autonomy. The circumstances of young people's lives, as well as young people's ability to meet and address the challenges they encounter as they become adults, have a direct impact on their future and the futures of their children and their country. The largest-ever generation of young people aged 10-24 is now making the transition from childhood to adulthood. One and a half billion of them — 86 percent - live in developing countries.

To provide a foundation of information on the lives of these young people, the U.S. National Academies published Growing Up Global: The Changing Transitions to Adulthood in Developing Countries in May 2005. [See Population Briefs, May 2005.] The volume detailed the findings of an expert panel — led by Cynthia B. Lloyd, Population Council director of social science researchon transitions to adulthood in developing countries. As part of its three-year information-gathering process, the panel commissioned background papers to provide more focused treatment of certain issues where existing literature was lacking. These papers informed the initial publication.

Ten of these background papers were selected by the editors for publication in a companion volume, The Changing
Transitions to Adulthood in Developing Countries: Selected Studies, which was published in December 2005. Some of the most important contributions of the volume are its essays on adolescents in China and on adolescent marriage. China has not participated in the Demographic and Health Surveys (DHS) program - a major source of comparative data for the panel report - and other data from China were not accessible to the panel. These circumstances made this contribution particularly critical. And, while marriage as an institution has been studied, its specific effects on adolescents have garnered little attention.

\section{Adolescents in China}

Emily Hannum of the University of Pennsylvania and Jihong Liu of the Harvard School of Public Health consider the case of adolescents in China, the most populous country in the world. The authors draw on a variety of information sources, including reports, policy documents, surveys, and census data from the Chinese government and the U.S. Census Bureau's International Data Base.

China currently accounts for more than 20 percent of young people in the developing world, and is also one of the countries in which economic development and transformation have been occurring most rapidly in recent decades. The authors find that, on average, this market-reform period has benefited the lives of many adolescents. Schooling has increased, and adolescent labor has decreased.
The average age at marriage rose in the 1990s — with the vast majority of males and females getting married after age 20 - and is high for the developing world. Thus, marriage is unlikely to compete directly with educational opportunities except at the very highest levels of education. Low fertility rates suggest that women's childrearing responsibilities in China may compete less with other opportunities than in many other developing countries.

Although many of the benefits of improved standards of living have been shared across social groups, social and economic inequalities are becoming more accentuated. Wealthier urban youth are beginning to experience problems with overeating, while some rural youth still face malnutrition. Suicide rates are dramatically higher among rural adolescents and young adults — especially young rural women - than among urban youth. Wealthier adolescents and those in urban areas are more likely to attend school than their poorer rural counterparts. Finally, social changes in the reform period raise important concerns about behavioral health issues, especially smoking and sexual health. AIDS has the potential to become a staggering social problem in China if not successfully addressed in the near future.

\section{Adolescent marriage}

According to human rights and reproductive health advocates who have put "child mar- 


\section{Low Morale Found Among South African Nurses}

The emigration of trained professionals poses an ongoing challenge in South Africa. Among nurses, this phenomenon - and the pressure it places on nurses who remain-may be contributing to a high rate of maternal mortality in that country. The Population Council's Frontiers in Reproductive Health program, in collaboration with the University of Witwatersrand, conducted a study to learn more about the workloads, morale, and career plans of maternity nurses in South Africa.

The study was carried out in Limpopo, KwaZulu-Natal, and Mpumalanga provinces in South Africa. All public sector hospitals providing maternity services in the three provinces were notified of the study and then faxed a questionnaire. Site visits were made to 15 hospitals and 27 clinics.

\section{Workload challenges and poor motivation}

Overall, hospitals and clinics had vacancy rates of 23 percent and 27 percent respectively, with clinics in Mpumalanga having the highest percentage of positions that had been vacated. Turnover for skilled midwives was also high. Eighty-three percent of hospitals but only 11 percent of clinics had nurses specially trained in midwifery, and 42 percent of facilities reported that they had lost an advanced midwife during the last year.

The results suggest that although nursing staff turnover, shortages of staff, and workload are extremely problematic at some facilities, not all facilities are equally badly affected. In the sampled clinics, the mean workload was 770 clients per month per professional nurse. The mean number of deliveries performed per professional nurse per month in hospitals was 16.5. In terms of absenteeism, the study found that although a large number of days were taken off sick, these were often isolated days and not long periods of sick leave. The average length of service of sisters-in-charge (charge nurses) was more than five years. The mean

number of years that professional nurses had worked at a facility was nine years in Mpumalanga and KwaZulu-Natal and nearly six years in Limpopo.

A high percentage of nursing staff working in public facilities said they were discouraged, burnt out, and considering leaving the facility where they worked. Sixty percent of professional nurses agreed or strongly agreed with the statement, "These days I don't feel motivated to work as hard as I could," and

"When I get up in the morning, I dread baving to face another day at work."

43 percent agreed with the statement, "When I get up in the morning, I dread having to face another day at work."

\section{Reasons for leaving service}

A range of factors was associated with nurses considering going overseas. Pay levels, poor opportunities for promotion, feeling unsupported by management, and having bad relationships at work were all associated with lack of desire to stay in one's job. Nurses in the middle age group of 30-49 years and those with children under the age of 18 were more likely to be considering going overseas than younger or older nurses. Wanting a better future for their children and needing money to pay for school and university fees were mentioned as being key motivations for nurses going overseas.

It is not possible to discuss any issue related to health in South Africa without considering the impact of the HIV/AIDS epidemic. The epidemic was found to have a role, but not to be directly responsible for problems with nursing morale in maternity units. Only 15 percent of nurses said that the risk of catching HIV has made them think about leaving their jobs. Indeed, more nurses (37 percent) were worried about catching HIV outside of work.

The study found that both financial and nonfinancial factors influenced nurses' decisions on where to work. Good management and a well-equipped hospital were as influential in nurses' choices as a 15 percent pay increase. The qualitative data showed that various policy initiatives instigated by government to retain staff, such as an additional allowance for nurses working in rural areas, have had mixed outcomes. In the case of the rural allowance, only professional nurses (and not nursing assistants) receive extra pay when they work in rural areas. This means that nurses who receive the allowance feel badly for their colleagues and in many cases are faced with colleagues being uncooperative and saying, "You get the rural allowance, you do the work."

The researchers note that interventions are badly needed to improve this situation, even though the low morale may be an obstacle to successfully implementing such efforts. Policymakers need to pay more attention to how policies are implemented and to the impact of policies on the relationships among nurses, and between nurses and managers in facilities. The researchers recommend that improving facility management should be a priority of South Africa's National Department of Health. But they acknowledge that such a task may be challenging, since many facility managers themselves are demoralized.

\footnotetext{
SOURCE

Penn-Kekana, Loveday, Duane Blaauw, Khin San Tint, Desiree Monareng, and Jane Chege. 2005. Nursing Staff Dynamics and Implications for Maternal Health Provision in Public Health Facilities in the Context of HIVIAIDS. Washington, DC: Population Council.

OUTSIDE FUNDING

President's Emergency Plan for AIDS Relief and the United States Agency for International Development, South Africa Mission
} 


\section{Surviving Catastrophe: The Elderly in Cambodia}

For a period that began in the early 1970 s and lasted more than two decades, the Cambodian people were victims in turn of bloody civil war, genocide and starvation, and renewed civil war. During the reign of the Khmer Rouge between 1975 and 1979, an estimated 1.5 to 2 million people - more than 20 percent of the population-lost their lives. Today, Cambodians endure extreme poverty and one of the highest HIV infection rates in Asia. Many of the people who died during civil strife or because of HIV infection were the spouses, sons, and daughters of the current elderly population. Thus, in addition to having endured extreme trauma, these older people may now lack core family support. However, relatively little systematic data exist on the social and economic situation or the health of Cambodia's elderly.

To fill this information gap, Population Council demographer Zachary Zimmer and University of Michigan researcher John Knodel collaborated with Cambodian researchers Kiry Sovan Kim and Sina Puch of the Royal University of Phnom Penh. The investigators conducted the 2004 Survey of Elderly in Cambodia, a representative survey of 1,273 people aged 60 and older living in the six most populous provinces, including Phnom Penh. This study is the first comprehensive examination of the lives of the Cambodian elderly based on a widely representative sample. To learn more about the impact of HIV infection, the researchers collected supplementary data from a nonrandom sample of 100 older Cambodians who lost children over the last five years as a result of HIV and other illnesses.

In addition to providing information about Cambodia's elderly population, "one of our chief goals with this study is to strengthen the ability of Cambodian scientists to conduct social science research in their own country," states Zimmer. The Khmer Rouge destroyed research capacity in Cambodia by eliminating academic institutions. The researchers, who are working closely with faculty at the Royal University of Phnom Penh, published three studies based on the survey data and have several more papers planned.

\section{Percent of the elderly reporting limitations in activities of daily living in Cambodia compared to other countries}

\begin{tabular}{lccccc} 
& Cambodia & Burma & Indonesia & Philippines & Thailand \\
\hline Getting up from lying down & 18.8 & $7.8^{* * *}$ & $3.8^{* *}$ & na & na \\
Eating & 8.7 & $5.4^{* * *}$ & $3.1^{* * *}$ & $4.5^{* * *}$ & $3.7^{* * *}$ \\
Bathing & 8.4 & $6.4^{* *}$ & $3.0^{* * *}$ & 7.2 & $6.2^{* *}$ \\
Dressing & 6.2 & $5.0^{*}$ & $2.2^{* * *}$ & 5.9 & $3.2^{* * *}$ \\
At least one limitation & 23.0 & $10.5^{* *}$ & $5.6^{* * *}$ & $9.0^{* * *}$ & $7.6^{* *}$
\end{tabular}

${ }^{*}{ }^{*} p<.01 ;{ }^{*} p<.05 ;{ }^{*} p<.10$ when comparing proportion versus Cambodia Source: Zimmer 2005.

\section{A bistory of violence}

The survey revealed the devastation wrought during the short but lethal period of Khmer Rouge rule. More than 40 percent of Cambodians over the age of 60 lost at least one child, and close to 25 percent of the women lost a spouse in those four years. Despite this bitter legacy, almost all elderly Cambodians have living children, owing to a high fertility rate. In fact, older people in Cambodia today typically have more surviving children than do older people in Thailand, owing to a sharp decline in fertility in the latter country. The Cambodian elderly rely heavily on family support, usually living with children and receiving modest amounts of money and material goods from them.

The survey assessed health in a number of ways. For instance, it asked respondents about their ability to carry out four activities of daily living: eating, bathing, dressing, and getting up from lying down. Zimmer analyzed this data and compared it to similar data from Burma, Indonesia, the Philippines, and Thailand. He found that elderly people in Cambodia experience limitations in each of these activities at higher rates than found in any of the other four countries. Twenty-three percent of older Cambodians report difficulties with at least one of these activities, as compared with 10.5 percent of the elderly population in Burma, 9 percent in the Philippines, and even lower proportions in Thailand and Indonesia (see table).

Using the information about activities of daily living, Zimmer calculated the "active life expectancy," the expected remaining years of functional well-being, of elderly Cambodians. He found that women live longer than men but spend a greater proportion of their lives with disabilities. Not surprisingly, he found older age to be related to higher rates of limitation and less active lives.

"So far our research has shown that elderly Cambodians have faced harsh and traumatic circumstances, most notably war and extreme poverty," says Zimmer. "All of this has affected their quality of life. Their health is poor and their lives are difficult."

The study results point to a need for greater recognition by the government and international aid agencies of the requirements of this hitherto largely ignored segment of the population.

\footnotetext{
SOURCES

Knodel, John, Sovan Kiry Kim, Zachary Zimmer, and Sina Puch. 2005. "Older persons in Cambodia: A profile from the 2004 Survey of Elderly," Population Studies Center Research Report no. 05-576. Ann Arbor: University of Michigan.

Zimmer, Zachary. 2005. "Active life expectancy and functional limitations among older Cambodians: Results from a 2004 survey," Policy Research

Division Working Paper no. 201. New York: Population Council.

Zimmer, Zachary, John Knodel, Kiry Sovan Kim, and Sina Puch. 2005. "The impact of past conflicts and social disruption in Cambodia on the current generation of older adults," Population Studies Center Research Report no. 05-582. Ann Arbor: University of Michigan.

\section{OUTSIDE FUNDING}

The William and Flora Hewlett Foundation, the Andrew W. Mellon Foundation, the National Institute on Aging, the United Nations Population Fund/Cambodia, and the US National Institutes of Health 


\section{Ethical Implications of Working with Children}

To set up and evaluate programs for children and adolescents affected by HIV/AIDS requires solid data on their life situations and needs. Investigators and program managers gathering this information face thorny ethical issues. Are children who lack adult protection and guidance capable of understanding the potential consequences of participating in a studyin other words, can they give truly informed consent? Are survey questions about the death of parents or other sensitive subjects likely to cause anxiety or even emotional damage? Could visits from a researcher "brand" a child as HIV-affected and deepen the stigma he or she may already experience?

\section{Practical guidelines}

Few resources exist to help program managers and evaluators deal with the difficult and potentially harmful situations that may arise when working with children affected by HIV/AIDS. At the request of the U.S. Agency for International Development (USAID), a steering group was formed composed of representatives of the Horizons Program, Family Health International's IMPACT Program, UNICEF, and USAID to develop practical guidelines for those who work with young people in international settings. The insights and experiences of this group and others working in the field were collected and analyzed in a handbook, copies of which are available free of charge. (To request a print copy, send your mailing address to horizons@pcdc.org; or you can download a PDF at http://www.popcouncil.org/pdfs/ horizons/childrenethics.pdf.)

\section{Identifying challenges}

Recognizing that methods for working with adults cannot simply be transferred to young people, this new resource identifies challenges that confront program implementers and investigators who work with children and adolescents and proposes practical approaches to overcoming them.
Among the ethical questions the handbook explores in depth are:

- Is the data collection activity necessary and justified?

- Is the activity designed to elicit valid information?

- Have community and stakeholder concerns been considered?

- Have adverse consequences of the activity been anticipated?

- Are procedures in place to ensure that the activity proceeds ethically?

- Are there a clear plan and adequate funding for follow-up activities?

\section{"Gathering informa-}

tion from children

requires additional

precautions to protect

their confidentiality,

privacy, and emo-

tional well-being."

The handbook also provides case studies that highlight the roles of interviewers, program managers, data analysts, and others in ensuring that child-related activities are not harmful or unethical. These vivid descriptions illustrate real-life struggles with ethical dilemmas and offer useful insights into appropriate approaches to working with youth. They are not examples of best practices: some frankly identify missed opportunities or oversights and examine the lessons to be learned.

As groundwork for the development of the publication, an expert consultation meeting took place in 2003. The gathering included researchers and service providers with expertise in psychology, child development, ethics, pediatrics, sociology, anthropology, and social work. This broad mix of perspectives and expertise led to a fruitful exchange about both ethical concerns and the practical issues involved in implementing effective standards.

Participants discussed the ethical responsibilities of professionals working with children affected by AIDS and other difficult situations, recognizing that such children often face poverty, stigma, or abuse. Participants agreed that program managers and researchers must take steps in advance to ensure that referral systems to local services are in place to help children in these situations, and that both parents or guardians and children know that abuse will be reported to the appropriate authorities.

Among other topics raised by participants and covered by the publication are gaining meaningful informed consent from children and creating opportunities for children to participate as advocates on their own behalf in study design, instrument development, and results interpretation.

"Because of the power imbalance between adult investigators and child informants, gathering information from children requires additional precautions to protect their confidentiality, privacy, and emotional well-being," said Katie Schenk of Horizons/Population Council, who coordinated the development of the handbook. "Involving everyone who participates in program development and research is critical to ensuring that these precautions are met."

SOURCE

Schenk, Katie and Jan Williamson. 2005. Ethical Approaches to Gathering Information from Children and Adolescents in International Settings: Guidelines and Resources. Washington, DC: Population Council.

OUTSIDE FUNDING

U.S. Agency for International Development 


\section{Council Researchers Wrestle with SUMO}

Little is understood about the molecular mechanisms that regulate sperm production - knowledge that would be key to the development of male contraceptives. Recent research conducted in the laboratory of Patricia L. Morris, a cell biologist and pharmacologist at the Population Council's Center for Biomedical Research, suggests that a protein known as SUMO-1 is involved in numerous aspects of this process. Gaining a greater understanding of SUMO's role in producing sperm, or spermatogenesis, may lead to insights about male infertility and reveal potential targets for male contraception.

\section{SUMOylation}

SUMO - which comes in two varieties, SUMO-1 and SUMO-2/3 - is a small protein that attaches to other proteins in a process known as SuMOylation. Cells use SUMOylation to alter proteins and influence their functions. SUMOylation can change a protein's ability to remain in place, communicate with cells, and participate in the activation of genes. Although SUMO-1 is found in the testis, almost nothing was previously known about its reproductive role.

From rodent and human testes, Morris and her team isolated sperm, germ cells (which give rise to sperm), somatic cells (critical supporting testicular cells not giving rise to sperm), and intact seminiferous tubules (tiny tubes in the testes in which germ cells grow and mature and sperm are produced). The human material came from biopsies taken from men with normal spermatogenesis and men with defective spermatogenesis. These procedures were approved by an institutional review committee, and the men gave informed consent. All of the men were being treated for infertility at Weill Cornell Medical Center. The men with normal spermatogenesis were infertile as a result of blockage in the transport of sperm.

"In both humans and rodents, we followed the presence of SUMO-1 and sumoylated proteins during spermatogenesis, from the early proliferating germ cell to the mature sperm," says Morris. "We have begun to char- acterize which proteins in which cells get sumoylated and at what point SUMOylation happens in the process of spermatogenesis."

For the first time, this study provides compelling support that in both humans and rodents, the regulation of spermatogenesis may be mediated by interactions between SUMO-1 and a molecule known as the androgen receptor. The male sex hormone testosterone influences cells by binding to the androgen receptor. Interactions between androgens and their receptor are essential for spermatogenesis. SUM0-1 may alter the course of spermato-

\section{SUMO-1 may alter}

the course of

spermatogenesis by

sumoylating the

androgen receptor.

genesis by sumoylating the androgen receptor, thereby altering androgen-dependent processes. The researchers also found important differences in the activity of SUMO-1 in rodents and in people. During a stage in spermatogenesis called the pachytene stage, genes in the $\mathrm{X}$ and $Y$ chromosomes (known as the sex chromosomes because they determine the sex of the offspring) become inactive. The genetic material then condenses into a structure known as the sex body. The findings suggest that SuMO-1 plays a different role in this process in people and in rodents.

SUM0-1 appears to be more abundant in the mouse sex body than in that of the human. In human pachytene spermatocytes, SUM0-1 and another factor that binds to DNA, known as a histone, show discrete patterns. In contrast, in rodent pachytene spermatocytes, the two proteins overlap the entire sex body.
Differences are also found in rodent and human SUM0-1 during meiosis - the type of cell division that results in sperm and eggs. Meiosis proceeds in several stages. During the first stage of meiosis in rodents, SUMO-1 is restricted to the sex chromosomes. In human spermatocytes during this stage, Morris's data indicate that SUM0-1 likely plays a role in the organization of other chromosomal regions as well.

"For example, our data indicate that in human male germ cells but not in those of rodents, SUMO-1 may play a role in centromere/kinetochore function," says Morris. The centromere is the pinched "waist" of a chromosome. The kinetochore is the part of the centromere to which spindle fibers attach during cell division. The spindle fibers help to separate the chromosomes properly into the resulting daughter cells. In most organisms (other than bacteria and algae), the molecular mechanisms that ensure accurate chromosome segregation during cell division are critical to maintaining the normal number of chromosomes. If a mechanism, such as the one facilitated by the kinetochore, is disrupted, meiosis could result in sperm or eggs that have more or less than the normal number of chromosomes. Embryos that result from such sperm or eggs are likely to miscarry or develop into infants with significant birth defects, such as Down syndrome.

Comparing SUMOylation in humans and rodents may provide important insights into centromere formation and kinetochore assembly.

\section{SOURCES}

Vigodner, Margarita, Tomomoto Ishikawa, Peter N. Schlegel, and Patricia L. Morris. Forthcoming. "SUMO-1, human male germ cell development and the androgen receptor in the testis of men with normal and abnormal spermatogenesis," American Journal of Physiology: Endocrinology and Metabolism (Translational Series). <http://ajpendo.physiology.org/papbyrecent.shtml> (doi:10.1152/ajpendo.00527.2005).

Vigodner, Margarita and Patricia L. Morris. 2005.

"Testicular expression of small ubiquitin-related modifier-1 (SUMO-1) supports multiple roles in spermatogenesis: Silencing of sex chromosomes in spermatocytes, spermatid microtubule nucleation, and nuclear reshaping," Developmental Biology 282: 480-492.

\section{OUTSIDE FUNDING}

George Frederick Jewett Foundation, F. M. Kirby Foundation, and National Institutes of Health 


\section{Transitions to Adulthood}

continued from page 1

riage" on the international agenda, marriage during the teenage years is particularly harmful (as well as much more common) for women: autonomy is limited, and sexual activities are uninformed and perhaps even coercive and dangerous to women's health.

Barbara Mensch of the Population Council, Susheela Singh of the Alan Guttmacher Institute, and John Casterline of Pennsylvania State University examine trends in the timing of first marriage among men and women in the developing world. They find that during the past 30 years in most developing-country regions, substantial declines have occurred in the proportion of men and women who are married during the teenage years. The clear exceptions are South America for both sexes, and West and Middle Africa and South and Southeast Asia for men only. While early marriage is declining, it is important to note that among women aged 20 to 24 interviewed by the DHS, one-third were still married prior to age 18 .

The researchers determined that scant data exist on the causes of changes in the timing of marriage, which may range from increased schooling for men and women to a transformation in global norms about the desirability of early marriage for women. The consequences of these changes for health and other outcomes are also unknown. In order to better understand the dynamics of marriage, surveys need to collect information on the social, cultural, and economic factors that affect life decisions among young people. Analyses of such data will permit the development of a more nuanced picture of one of the key transitions in the passage from adolescence to adulthood.

India, like China, accounts for more than a fifth of the young people in the developing world. Shireen Jejeebhoy of the Population Council and Shiva Halli of the University of Manitoba examine changes in marriage patterns among successive age groups of women in rural Uttar Pradesh and Tamil Nadu, provinces with two culturally distinct social systems. In both provinces, marriage age has been increasing moderately but at different paces: In Uttar Pradesh early adolescent marriages (under age 15) have declined perceptibly, yet about two-thirds of recently married women had married by the time they were age 18. Among women in Tamil Nadu, in contrast, marriage is increasingly being delayed beyond adolescence. Similar factors appear to be associated with the increase in marriage age in these two settings. Education, even only at the primary level, is associated with sharply increased marital age. Compared to the Muslims of Uttar Pradesh, the Hindus of this state marry significantly earlier, while both Muslim and Hindu women from Tamil Nadu are significantly more likely to delay marriage.

The research shows that while education is significantly related to older age at marriage, and while secondary education is associated with exercise of choice in marriage timing and partner, education is also related to increased dowry payments. Conversely, while premarital economic activity is unrelated to marriage age or marriage-related decisionmaking, it is significantly associated with reduced dowry payments. These findings suggest that strategies to delay marriage, enhance marriage-related decisionmaking, and counter the practice of dowry may need to expand beyond education and employment and focus on such issues as building community awareness of the negative effects of early marriage, countering fears of allowing girls to remain single, providing for the acquisition of usable vocational and life skills, and enhancing young women's access to and control over economic resources and decisionmaking related to their life choices.

Agnes Quisumbing of the International Food Policy Research Institute and Kelly Hallman of the Population Council analyze data on husbands' and wives' ages, education, and assets at marriage in Bangladesh, Ethiopia, Guatemala, Mexico, the Philippines, and South Africa.

In these six countries, age at marriage is increasing for husbands and wives, with the exception of Bangladesh for men and Ethiopia for men and women. In four of the countries, age differences between spouses have decreased. Differences between spouses in age at marriage have not decreased in South Africa and the Philippines, the two countries in the study where women's ages at marriage are the highest.

The amount of schooling completed before marriage has also been increasing for both men and women, except for men in Bangladesh. In three of the countries, differences in the amount of schooling received by husbands and wives have also decreased. The exceptions are Guatemala and the Philippines, where the difference in years of schooling has not changed over time, and Ethiopia, where the difference is increasing, with husbands receiving more education.

Husbands' assets at marriage have increased over time in four countries, declining only in Ethiopia and remaining constant in the Philippines. Wives' assets at marriage have increased in Guatemala, Mexico, and South Africa, remained constant in the Philippines, and declined in Bangladesh and Ethiopia.

The reduction of husband-wife gaps in age at marriage and in schooling indicates potential improvements in the balance of power within the family, but the distribution of assets at marriage continues to favor husbands. It remains to be seen whether the reductions in gender gaps in age and schooling will offset the persistent gender gaps in wealth.

The studies in this volume served as vital information sources for the National Academies report on the transitions to adulthood in developing countries. They complement the report and provide useful contributions in their own right. "Our hope is that these studies will be useful to those charged with making and implementing public policy, as well as to scholars from different disciplines and leaders of civil society organizations wishing to build on the panel's foundation," says Lloyd.

\section{SOURCE}

National Research Council. 2005. The Changing Transitions to Adulthood in Developing Countries: Selected Studies. Cynthia B. Lloyd, Jere R. Behrman, Nelly P. Stromquist, and Barney Cohen (eds.). Panel on Transitions to Adulthood in Developing Countries. Committee on Population. Division of Behavioral and Social Sciences and Education. Washington, DC: The National Academies Press. 


\section{Biomedicine}

Cheng, Chuen-yan, Dolores D. Mruk, Bruno Silvestrini, Michelle Bonanomi, Ching-hang Wong, Michelle K.Y. Siu, Nikki P.Y. Lee, Wing-Yee Lui, and Meng-Yun Mo. "AF-2364 [1-(2,4-dichlorobenzyl)-1H-indazole-3-carbohydrazide] is a potential male contraceptive: A review of recent data," Contraception 72(4): 251-261.

Fraser, Ian S., Edith Weisberg, Vivian Brache, Francisco Alvarez, Rebeca Massai, Daniel R. Mishell, Jr., Dan Apter, Judi Gale, Yun-yen Tsong, and Irving Sivin. “Serum Nestorone ${ }^{\circledast}$ and ethinyl estradiol levels, and ovulation inhibition in women using three different dosage combinations of a Nestorone progestogenethinyl estradiol contraceptive vaginal ring on a bleeding-signaled regimen," Contraception 72(1): 40-45.

Hardy, Matthew P., Hui-Bao Gao, Qiang Dong, Renshan Ge, Qian Wang, Wei Ran Chai, Xing Feng, and Chantal Sottas. "Stress hormone and male reproductive function," Cell and Tissue Research 322(1): 147-153.

Lee, Nikki P.Y., Dolores D. Mruk, Ching-hang Wong, and Chuen-yan Cheng. "Regulation of Sertoli-germ cell adherens junction dynamics in the testis via the nitric oxide synthase (NOS)/cGMP/protein kinase G (PRKG)/B-catenin (CATNB) signaling pathway: An in vitro and in vivo study," Biology of Reproduction 73(3): 458-471.

Mukai, Motoko, Qiang Dong, Matthew P. Hardy, Hiroaki Kiyokawa, Richard E. Peterson, and Paul S. Cooke. "Altered prostatic epithelial proliferation and apoptosis, prostatic development and serum testosterone in mice lacking cyclin-dependent kinase inhibitors," Biology of Reproduction 73(5): 951-958.

Sitruk-Ware, Régine. "Estrogen and progestogens: Different routes of administration (editorial)," Climateric 8(suppl 1): 1-2.

"Pharmacology of different progestogens: The special case of drospirenone," Climateric 8(suppl 3): 4-12.

Sitruk-Ware, Régine and Pirjo Inki. “The levonorgestrel intrauterine system: Long-term contraception and therapeutic effects," Women's Health 1(2): 171-182.

Sprague, Wendy S., Melissa Pope, and Edward A. Hoover. "Culture and comparison of feline myeloid dendritic cells vs macrophages," Journal of Comparative Pathology 133(2-3): 136-145.

Vargas, Louis A., Richard Sewell, Aileen Marshall, Josephine Galatioto, Yun-yen Tsong, James F. Catterall, and Gary R. Hunnicutt. "Immune complex deposition in adult male Sprague-Dawley rats chronically immunized with GnRH," American Journal of Reproductive Immunology 54(5): 292-310.

Venken, Katrien, Steven Boonen, Erik Van Herck, Liesbeth Vandenput, Narender Kumar, Régine SitrukWare, Kalyan Sundaram, Roger Bouillon, and Dirk Vanderschueren. "Bone and muscle protective potential of the prostate-sparing synthetic androgen $7 \alpha$ methyl-19-nortestosterone: Evidence from the aged orchidectomized male rat model," Bone 36(4): 663-670.

Weisberg, Edith, Vivian Brache, Francisco Alvarez, Rebeca Massai, Daniel R. Mishell, Jr., Dan Apter, Judi Gale, Irving Sivin, Yun-yen Tsong, and Ian S. Fraser. "Clinical performance and menstrual bleeding patterns with three dosage combinations of a Nestorone ${ }^{\circledR}$ progestogen/ethinyl estradiol contraceptive vaginal ring used on a bleeding-signaled regimen,"

Contraception 72(1): 46-52.
Weissman, Ben-Avi, Enmei Niu, Renshan S. Ge, Chantal M. Sottas, Michael Holmes, James C. Hutson, and Matthew P. Hardy. "Paracrine modulation of androgen synthesis in rat Leydig cells by nitric oxide," Journal of Andrology 26(3): 369-378.

Wong, Ching-hang and Chuen-yan Cheng. "Mitogenactivated protein kinases, adherens junction dynamics, and spermatogenesis: A review of recent data,"

Developmental Biology 286(1): 1-15.

Xia, Weiliang, Dolores D. Mruk, Will M. Lee, and Chuenyan Cheng. "Cytokines and junction restructuring during spermatogenesis: A lesson to learn from the testis," Cytokine and Growth Factor Reviews 16(4-5): 469-493.

Xia, Weiliang, Ching-hang Wong, Nikki P.Y. Lee, Will M. Lee, and Chuen-yan Cheng. "Disruption of Sertoli-germ cell adhesion function in the seminiferous epithelium of the rat testis can be limited to adherens junctions without affecting the blood-testis barrier integrity: An in vivo study using an androgen suppression model," Journal of Cellular Physiology 205(1): 141-157.

Yan, Helen H.N. and Chuen-yan Cheng. "Blood-testis barrier dynamics are regulated by an engagement/disengagement mechanism between tight and adherens junctions via peripheral adaptors," Proceedings of the National Academy of Sciences 102(33): 11722-11727.

\section{Gender and Family Dynamics}

Deuba, Arzu Rana and Pinky Singh Rana. "A study on linkages between domestic violence and pregnancy." Kathmandu: SAMANATA — Institute for Social and Gender Equality.

Espinoza, Henry. "Using edutainment and social activities to challenge machismo in Nicaragua: The example of Somos Diferentes, Somos Iguales," Sexual Health Exchange 2005(2): 9-10. Amsterdam: Royal Tropical Institute.

Ghuman, Sharon, Helen J. Lee, and Herbert L. Smith. "Measurement of women's autonomy according to women and their husbands: Results from five Asian countries," Social Science Research 35(1): 1-28.

Noumbissi, Amadou, Ayaga A. Bawah, and Tukufu Zuberi. "Parental survival and residential patterns in South Africa," in Tukufu Zuberi, Amson Sibanda, and Eric Udjo (eds.), The Demography of South Africa. New York: Sharpe Publications, pp. 160-180.

Rogow, Deborah and Nicole Haberland. "Sexuality and relationships education: Toward a social studies approach," Sex Education 5(4): 333-344.

Verma, Ravi, Julie Pulerwitz, Vaishali Sharma Mahendra, Sujata Khandekar, and Gary Barker. "Promoting gender equity among young men: Positive experiences of the Yari-dosti project in India," Sexual Health Exchange 2005(2): 5-6. Amsterdam: Royal Tropical Institute.

Yonder, Ayse, Sengul Akcar, and Prema Gopalan. "Women's participation in disaster relief and recovery," SEEDS no. 22. New York: Population Council.

\section{HIV/AIDS}

Baiden, Frank, Rita Baiden, John Williams, Patricia Akweongo, Christine Clerk, Cornelius Debpuur, James F. Phillips, and Abraham Hodgson. "Review of antenatal-linked voluntary counseling and HIV testing in subSaharan Africa: Lessons and options for Ghana," Ghana Medical Journa/ 39(1): 8-13.
Barnes, Carolyn. "Microcredit and households coping with HIV/AIDS: A case study from Zimbabwe," Journal of Microfinance 7(1): 55-77.

Braunstein, Sarah and Janneke van de Wijgert. "Preferences and practices related to vaginal lubrication: Implications for microbicide acceptability and clinical testing," Journal of Women's Health 14(5): 424-433.

Brown, Lisanne, Tonya Thurman, and Leslie Snider. "Strengthening the psychosocial well-being of youthheaded households in Rwanda: Baseline findings from an intervention trial." Washington, DC: Population Council.

Busza, Joanna. “How does a risk group perceive risk? Voices of Vietnamese sex workers in Cambodia," Journal of Psychology and Human Sexuality 17(1/2): 65-82.

Cooper, Diane, Hillary Bracken, Landon Myer, Virginia Zweigenthal, Jane Harries, Phyllis Orner, Nontuthuzelo Manjezi, and Pumeza Ngubane. "Reproductive intentions and choices among HIV-infected individuals in Cape Town, South Africa: Lessons for reproductive policy and service provision from a qualitative study," Policy Brief, September. Cape Town: Women's Health Research Unit, University of Cape Town, and Population Council.

Duerr, Ann, Stephen Hurst, Athena Kourtis, Naomi Rutenberg, and Denise J. Jamieson. "Integrating family planning and prevention of mother-to-child HIV transmission in resource-limited settings," Lancet 366(9481): 261-263.

Horizons Program and University of Cape Town Faculty of Health Sciences. "Exploring current practices in paediatric antiretroviral roll-out and integration with early childhood programmes in South Africa: A rapid situational analysis," Horizons Research Update. Washington, DC: Population Council.

Juma, Milka, Margaret Mwaniki, and Charity Muturi. "Evaluating the Kenya Girl Guides Association's HIV/AIDS peer education program for younger youth: Baseline results." Nairobi: Population Council.

Kaai, Susan, Carolyn Baek, Scott Geibel, Peter McOdida, Benson Ulo, Grace Muthumbi, Carol Matiko, and Naomi Rutenberg. "HIV serostatus and infant feeding counseling and practice: Findings from a baseline study among the urban poor in Kenya," Horizons Research Update. Washington, DC: Population Council.

Kaai, Susan, Avina Sarna, Johannes van Dam, and Mark Hawken. "Operations research," in Delivering Antiretroviral Therapy in Resource-Constrained Settings. Arlington, VA: Family Health International, pp. 105-112.

Mahendra, Vaishali Sharma, Laelia Gilborn, Rupa Mudoi, Sarita Jadav, Shalini Bharat, Indrani Gupta, Bitra George, Luke Samson, Arhcana Panda, and Shweta Bajaj. "Improving the hospital environment for people living with HIV/AIDS in India: Findings from a pilot study to reduce stigma and discrimination," Horizons Research Update. Washington, DC: Population Council.

Meekers, Dominique and Kerry Richter. "Factors associated with use of the female condom in Zimbabwe," International Family Planning Perspectives 31(1): 30-37. Munyao, Paul, Avina Sarna, Stanley Luchters, Scott Geibel, Khadija Shikely, Kishor Mandaliya, Susan Kaai, Mark Hawken, Johannes van Dam, and Marleen Temmerman. "How feasible is a DAART strategy to promote adherence to ART? Lessons from Mombasa, Kenya," Horizons Research Update. Nairobi: Population Council. 
Ndhlovu, Lewis, Catherine Searle, Johannes van Dam, Yodwa Mzaidume, Bareng Rasego, and Solly Moema. "Reducing the transmission of HIV and sexually transmitted infections in a mining community: Findings from the Carletonville Mothusimpilo intervention project: 1998 to 2001," Horizons Final Report. Washington, DC: Population Council.

Onyango-Ouma, W., Harriet Birungi, and Scott Geibel. "Understanding the HIV/STI risks and prevention needs of men who have sex with men in Nairobi, Kenya." Nairobi: Population Council.

Penn-Kekana, Loveday, Duane Blaauw, Khin S. Tint, Desiree Monareng, and Jane Chege. "Nursing staff dynamics and implications for maternal health provision in public health facilities in the context of HIV/AIDS," FRONTIERS Final Report. Washington, DC: Population Council.

Rutenberg, Naomi and Carolyn Baek. "Field experiences integrating family planning into programs to prevent mother-to-child transmission of HIV," Studies in Family Planning 36(3): 235-245.

Sarna, Avina, Stanley Luchters, Scott Geibel, Paul Munyao, Susan Kaai, Khadija Shikely, Kishor Mandaliya, Mark Hawken, Johannes van Dam, and Marleen Temmerman. "Promoting adherence to antiretroviral therapy through a directly administered antiretroviral therapy (DAART) strategy in Mombasa, Kenya," Horizons Research Update. Nairobi: Population Council.

Sarna, Avina, Stanley Luchters, Susan Kaai, Paul Munyao, Scott Geibel, Khadija Shikely, Kishor Mandaliya, Mark Hawken, Johannes van Dam, and Marleen Temmerman. “Does being treated with HAART affect the sexual risk behavior of people living with HIV/AIDS? Insights from Mombasa, Kenya," Horizons Research Update. Nairobi: Population Council.

Schenk, Katie. "Reducing stigma through care and support," in Nick Perkins and Sam Mulyanga (eds.), My Right to Belong: Stories of Stigma Reduction Efforts Across Africa. Nairobi: ActionAid International Africa.

Schenk, Katie and Jan Williamson. Ethical Approaches to Gathering Information from Children and Adolescents in International Settings: Guidelines and Resources. Washington, DC: Population Council.

\section{Infants and Children}

Ghuman, Sharon, Jere Behrman, Judith Borja, Socorro Gultiano, and Elizabeth King. "Family background, service providers, and early childhood development in the Philippines: Proxies and interactions," Economic Development and Cultural Change 54(1): 129-164.

\section{Quality of Care}

Chege, Jane, lan Askew, Nzwakie Mosery, Mbal Ndube-Nxumalo, Busi Kunene, Mags Beksinska, Janet Dalton, Ester Snyman, Wilem Sturm, and Preshny Moodley. "Feasibility of introducing a comprehensive package of antenatal care services in rural public clinics in South Africa," FRONTIERS Final Report. Washington, DC: Population Council.

Das, N.P., Urvi Shah, Varsha Chitania, Pratibha Patel, M.E. Khan, Anurag Mishra, and James R. Foreit. "Systematic screening to integrate reproductive health services in India," FRONTIERS Final Report.

Washington, DC: Population Council.

Fikree, Fariyal F, Sarah Saleem, and Neelofar Sami. "A quality of care issue: Appropriate use and efficacy knowledge of five contraceptive methods: Views of men and women living in low socioeconomic settlements of Karachi, Pakistan," Journal of Pakistan Medical Association 55(9): 363-368.
Foreit, James R., Ricardo Vernon, and Patricia Riveros Hamel. "Use of systematic screening to increase the provision of reproductive health services in Bolivia," FRONTIERS Final Report. Washington, DC: Population Council.

Montufar, Edwin, Carlos Morales, Ricardo Vernon, Carlos Brambila, and Jorge Solórzano. “Improving access to long-term contraceptives in rural Guatemala through the Ministry of Health," FRONTIERS Final Report. Washington, DC: Population Council.

Sanogo, Diouratié, Ricardo Vernon, James R. Foreit, Awa Seck, Colonel A. Adoye, Laty G. Ndoye, Cheikh B. Diop, Balla M. Mboup, and Omar Sarr. "Using systematic screening to increase integration of reproductive health services delivery in Senegal," FRONTIERS Final Report. Washington, DC: Population Council.

Sathar, Zeba A., Anrudh Jain, Saumya RamaRao, Minhaj ul Haque, and Jacqueline Kim. "Introducing client-centered reproductive health services in a Pakistani setting," Studies in Family Planning 36(3): 221-234.

Vernon, Ricardo, James R. Foreit, Fiorella Mancini, Suyapa Pavón, and Jheisy Torres. "Systematic screening as a strategy to increase services integration and revenues in Honduras," FRONTIERS Final Report. Washington, DC: Population Council.

\section{Reproductive Health}

Bracken, Hillary and Vijaya Nidadavolu. "Mixed messages? An analysis of communicating materials on abortion and sex determination in Rajasthan," Economic and Political Weekly 40(35): 3856-3862.

Bratt, John, Nahla Abdel-Tawab, Magdi A. Ibrahim, and Mohamed Idrees. "Willingness-to-pay for services provided by the Clinical Services Improvement Project (CSI) in Egypt," Summary of Key Findings. Cairo: Population Council (in Arabic).

Bur, Mona. "Advancing knowledge of psycho-sexua effects of female genital cutting: Assessing the evidence: Seminar report, Alexandria, Egypt." Cairo: Population Council.

“Cómo pueden las y los jóvenes comunicarse en temas de sexualidad planificación familia," Información Jóvenes México no. 3. Mexico City: Population Council. "EC and young people/La jeunesse et le EC," ECafrique Bulletin 3(1): 1-20.

Gonzales Salguero, Fernando, Antonieta Martin, Rosario Pérez Mendoza, and Ricardo Vernon. "Crosscultural adaptation of reproductive health services in Bolivia," FRONTIERS Final Report. Washington, DC: Population Council.

"Introducing magnesium sulphate for the management of pregnancy-induced hypertension," Safe Motherhood Policy Alert. Nairobi: Population Council.

"Los y las jóvenes y su derecho a la planificación familiar," Informacion Jóvenes Mexico no. 1. Mexico City: Population Council.

Khan, M.E., Anurag Mishra, and Sudhakar Morankar. "Views on young men's sexual and reproductive health needs in Uttaranchal," Research Update no. 4. New Delhi: Population Council.

Khan, M.E. and Sohini Roychowdhury. "Poribar porikolpona o projonon shastho: Shokoler ki ki jana dorkar," key messages booklet for rickshaw pullers. Dhaka: Population Council.

Mullick, Saiqa, Mags Beksinska, and Sibekezelo Msomi. "Treatment for syphilis in antenatal care: Compliance with the three dose standard treatment regimen," Sexually Transmitted Infections 81(3): 220-222.
Mullick, Saiqa, Deborah Watson-Jones, Mags Beksinska, and David Mabey. "Sexually transmitted infections in pregnancy: Prevalence, impact on pregnancy outcomes, and approach to treatment in developing countries," Sexually Transmitted Infections 81(4): 294-302.

Nguyen T.N. Ngoc, Nancy L. Sloan, Tran S. Thach, Le K.B. Liem, and Beverly Winikoff. "Incidence of postpartum infection after vaginal delivery in Vietnam," Journal of Health, Population, and Nutrition 23(2): $121-130$

"Postabortion family planning benefits clients and providers," Program Brief no. 4. Washington, DC: Population Council.

“Promoting role model of 'responsible man': Gatekeepers' views of addressing young men's sexua and reproductive health needs in Uttaranchal, India," Asia and Near East Regional OR Summary no. 6. New Delhi: Population Council.

"Repositioning post partum care in Kenya," Safe Motherhood Policy Alert. Nairobi: Population Council.

Rob, Ubaidur. "Men and reproductive health," World Population Day special supplement. Dhaka: Directorate General of Family Planning, Ministry of Health and Family Welfare.

Rob, Ubaidur, Md. Noorunnabi Taluker, Md. Mahabubul Anwar, Laila Rahman, and Marium ul Mutahara. Health Sector Reform: Trends and Lessons Learned. Dhaka: Population Council and Canadian International Development Agency.

"Safai ki jankari," training manual. New Delhi: Population Council.

"La salud reproductiva de los y las jóvenes de áreas rurales," Información Jóvenes México no. 2. Mexico City: Population Council.

Sebastian, Mary P., Shiv Kumar, M.E. Khan, Chander Shekhar, and N.K. Gupta. "Studying the utilization of emergency contraceptive services through paramedics in India," Research Update no. 5. New Delhi: Population Council.

Shaaban, Layla M. and Sarah Harbison. "Reaching the tipping point against female genital mutilation," Lancet 366(9483): 347-349.

"The SMNH implementation framework for districts," Safe Motherhood Policy Alert. Nairobi: Population Council.

“Taking maternal services to pregnant women: The community midwifery model," Safe Motherhood Policy Alert. Nairobi: Population Council.

“Transferring Ghana's system of evidence-based health program development: Program for an initial exchange with Sierra Leone and Burkina Faso." Washington, DC: Population Council.

Walraven, Gijs, Jennifer Blum, Yusupha Dampha, Maimuna Sowe, Linda Morison, Beverly Winikoff, and Nancy L. Sloan. "Misoprostol in the management of the third stage of labour in the home delivery setting in rural Gambia: A randomized trial," BJOG: An International Journal of Obstetrics and Gynaecology 112(9): 1277-1283.

Weeks, Andrew, Godfrey Alia, Jennifer Blum, Beverly Winikoff, Paul Ekwaru, Jill Durocher, and Florence Mirembe. "A randomized trial of misoprostol compared with manual vacuum aspiration for incomplete abortion," Obstetrics and Gynecology 106(3): 540-547. 


\section{Social Science}

Bawah, Ayaga A. and Fred N. Binka. "How many years of life could be saved if malaria were eliminated from a hyperendemic area of northern Ghana?" Policy Research Division Working Paper no. 203. New York: Population Council.

Bawah, Ayaga and Tukufu Zuberi. "Socioeconomic status and child mortality in Southern Africa," Genus 61(1-2): 55-83.

Bongaarts, John. "The causes of stalled fertility transitions," Policy Research Division Working Paper no. 204. New York: Population Council.

."Five period longevity measures," Demographic Research 13(21): 547-558.

Bongaarts, John and Griffith Feeney. "The quantum and tempo of life-cycle events," Policy Research Division Working Paper no. 207. New York: Population Council.

Keith-Brown, Kimberli. "Investing for life: Making the link between public spending and the reduction of maternal mortality," Mexico City: Fundar Centro de Análisis e Investigación.

Knodel, John, Sovan Kiry Kim, Zachary Zimmer, and Sina Puch. "Older persons in Cambodia: A profile from the 2004 Survey of Elderly," Population Studies Center Research Report no. 05-576. Ann Arbor: University of Michigan.

McNicoll, Geoffrey. "Population and sustainability," Policy Research Division Working Paper no. 205. New York: Population Council.

Review of Gordon H. Sellon, Jr. (ed.), Global Demographic Change: Economic Impacts and Policy Challenges; A Symposium Sponsored by the Federal Reserve Bank of Kansas City, Jackson Hole, Wyoming, August 26-28, 2004, Population and Development Review 31(4): 776-778.

Mensch, Barbara S., Monica J. Grant, and Ann K. Blanc. "The changing context of sexual initiation in sub-Saharan Africa," Policy Research Division Working Paper no. 206. New York: Population Council.

Neumayer, Eric and Laura Spess. "Do bilateral investment treaties increase foreign direct investment to developing countries?" World Development 33(10): 1567-1585.

Nyonator, Frank K., Tanya C. Jones, Robert A. Miller James F. Phillips, and John K. Awoonor-Williams. "Guiding the Ghana Community-based Health Planning and Services approach to scaling up with qualitative systems appraisal," International Quarterly of Community Health Education 23(3): 189-213.

Phillips, James F., Ayaga A. Bawah, and Fred N. Binka. "Accelerating reproductive and child health program development: The Navrongo initiative in Ghana," Policy Research Division Working Paper no. 208. New York: Population Council.

Rob, Ubaidur. "Policy issues in Bangladesh population planning program," The Guardian, pp. 50-51.

Zimmer, Zachary. "Health and living arrangement transitions among China's oldest-old," Research on Aging 27(5): 526-555.

Review of Roger Mark Selya, Development and Demographic Change in Taiwan 1945-1995, Population and Development Review 31(4): 780-781.

Zimmer, Zachary and Julia Dayton. "Older adults in sub-Saharan Africa living with children and grandchildren," Population Studies 59(3): 295-312.
Zimmer, Zachary, John Knodel, Sovan Kiry Kim, and Sina Puch. "The impact of past conflicts and social disruption in Cambodia on the current generation of older adults," Population Studies Center Research Report no. 05-582. Ann Arbor: University of Michigan.

\section{Transitions to Adulthood}

Amin, Sajeda. "Kishori Abhijan: A pilot project to empower adolescent girls," Promoting Healthy, Safe, and Productive Transitions to Adulthood Brief no. 13. New York: Population Council.

Brady, Martha. "Letting girls play: Using sport to create safe spaces and build social assets," Promoting Healthy, Safe, and Productive Transitions to Adulthood Brief no. 1. New York: Population Council.

Brady, Martha, Abeer Salem, and Nadia Zibani. "Bringing new opportunities to adolescent girls in socially conservative settings: The Ishraq program in rural Upper Egypt," Promoting Healthy, Safe, and Productive Transitions to Adulthood Brief no. 12. New York: Population Council.

Brady, Martha and Lydia Saloucou. "Addressing the needs of married adolescent girls in Burkina Faso," Promoting Healthy, Safe, and Productive Transitions to Adulthood Brief no. 9. New York: Population Council (also available in French)

Bruce, Judith. "Child marriage in the context of the HIV epidemic," Promoting Healthy, Safe, and Productive Transitions to Adulthood Brief no. 11. New York: Population Council (also available in French).

Catino, Jennifer, Kelly Hallman, and Marta Julia Ruiz. "Building skills to enhance life opportunities for Mayan girls," Promoting Healthy, Safe, and Productive Transitions to Adulthood Brief no. 5. New York: Population Council.

"Child marriage briefing," a series of two-page briefs on Ethiopia, Mali, Mozambique, Nigeria, and Zambia. New York: Population Council.

Chong, Erica. "Analyzing data to target the most vulnerable adolescents and to identify their needs," Promoting Healthy, Safe, and Productive Transitions to Adulthood Brief no. 10. New York: Population Council (also available in French).

Chong, Erica and Nicole Haberland. "Child marriage: A cause for global action," Promoting Healthy, Safe, and Productive Transitions to Adulthood Brief no. 14. New York: Population Council.

Erulkar, Annabel and Tekle-Ab Mekbib. "Reaching vulnerable youth in Ethiopia," Promoting Healthy, Safe, and Productive Transitions to Adulthood Brief no. 6. New York: Population Council (also available in French).

Grant, Monica, Barbara S. Mensch, and Mary P. Sebastian. "Introducing adolescent livelihoods training in the slums of Allahabad, India," Promoting Healthy, Safe, and Productive Transitions to Adulthood Brief no. 2. New York: Population Council.

Haberland, Nicole. “Supporting married girls: Young wives and young mothers," Promoting Healthy, Safe, and Productive Transitions to Adulthood Brief no. 3. New York: Population Council.

Haberland, Nicole, Erica L. Chong, Hillary Bracken, and Chris Parker. "Early marriage and adolescent girls," YouthLens on Reproductive Health and HIV/AIDS no. 15. Arlington, VA: YouthNet.
Hallman, Kelly and Judith A. Diers. "Providing safe spaces, financial skills, and HIV/AIDS awareness for vulnerable South African youth," Promoting Healthy, Safe, and Productive Transitions to Adulthood Brief no. 4. New York: Population Council (also available in French).

Hewett, Paul C. and Cynthia B. Lloyd. "Progress toward education for all: Trends and current challenges for sub-Saharan Africa," in Cynthia B. Lloyd, Jere R. Behrman, Nelly P. Stromquist, and Barney Cohen (eds.), The Changing Transitions to Adulthood in Developing Countries: Selected Studies. Washington, DC: National Academies Press, pp. 84-117.

Jejeebhoy, Shireen J. "Investigating nonconsensua sex: Silence threatens adolescents' health and rights," Promoting Healthy, Safe, and Productive Transitions to Adulthood Brief no. 7. New York: Population Council.

Jejeebhoy, Shireen J. and Shiva S. Halli. "Marriage patterns in rural India: Influence of sociocultural context," in Cynthia B. Lloyd, Jere R. Behrman, Nelly P. Stromquist, and Barney Cohen (eds.), The Changing Transitions to Adulthood in Developing Countries: Selected Studies. Washington, DC: National Academies Press, pp. 172-199.

Lloyd, Cynthia B. Review of United Nations, World Youth Report 2003: The Global Situation of Young People, Studies in Family Planning 36(4): 326-327.

Lloyd, Cynthia B., Jere R. Behrman, Nelly P. Stromquist, and Barney Cohen (eds.). The Changing Transitions to Adulthood in Developing Countries: Selected Studies. Washington, DC: National Academies Press.

Lloyd, Cynthia B., Jere R. Behrman, Nelly P. Stromquist, and Barney Cohen. "Introduction," in Cynthia B. Lloyd, Jere R. Behrman, Nelly P. Stromquist, and Barney Cohen (eds.), The Changing Transitions to Adulthood in Developing Countries: Selected Studies. Washington,

DC: National Academies Press, pp. 1-12.

Lloyd, Cynthia B. and Monica Grant. “Growing up in Pakistan: The separate experiences of males and females," in Cynthia B. Lloyd, Jere R. Behrman, Nelly P. Stromquist, and Barney Cohen (eds.), The Changing Transitions to Adulthood in Developing Countries: Selected Studies. Washington, DC: National Academies Press, pp. 320-366

Mensch, Barbara S., Susheela Singh, and John B. Casterline. "Trends in the timing of first marriage among men and women in the developing world," in Cynthia B. Lloyd, Jere R. Behrman, Nelly P. Stromquist, and Barney Cohen (eds.), The Changing Transitions to Adulthood in Developing Countries: Selected Studies. Washington, DC: National Academies Press, pp. 118-171.

“The Population Council's approach," Promoting Healthy, Safe, and Productive Transitions to Adulthood overview. New York: Population Council (also available in French).

Quisumbing, Agnes R. and Kelly Hallman. “Marriage in transition: Evidence on age, education, and assets from six developing countries," in Cynthia B. Lloyd, Jere R. Behrman, Nelly P. Stromquist, and Barney Cohen (eds.), The Changing Transitions to Adulthood in Developing Countries: Selected Studies. Washington, DC: National Academies Press, pp. 200-269.

Santhya, K.G. and Nicole Haberland. "Empowering young mothers in India," Promoting Healthy, Safe, and Productive Transitions to Adulthood Brief no. 8. New York: Population Council. 


\section{Population Council}

One Dag Hammarskjold Plaza, New York, NY 10017

Population Briefs is a research newsletter of the Population Council. The Council is an international, nonprofit, nongovernmental organization that seeks to improve the well-being and reproductive health of current and future generations around the world and to help achieve a humane, equitable, and sustainable balance between people and resources. The Council conducts biomedical social science, and public health research and helps build research capacities in developing countries. Established in 1952, the Council is governed by an international board of trustees. Its New York headquarters supports a global network of regional and country offices.

Writer/Editor: Gina Duclayan

Editorial Board: Cynthia B. Lloyd, Melissa May, Irving Sivin, C. Johannes van Dam Production Manager: Y. Christina Tse Production Artist: Sura Rosenthal Copyeditor: Robert Heidel Editorial Assistant: Jared Stamm Circulation: Debra Warn

Population Briefs is distributed without charge. Information in this newsletter may be reproduced without permission, provided it is distributed without charge and the source is acknowledged.

To receive e-mail when a new issue of Population Briefs is posted to the Population Council Web site, register at www.popcouncil.org/signup ISSN 1084-6786

(C)2006 The Population Council, Inc.

\section{IN THIS ISSUE}

TRANSITIONS TO ADULTHOOD

AIDS has the potential to become a staggering social problem in China if not successfully addressed in the near future.

See page 1

\section{SAFE MOTHERHOOD}

The emigration of nurses from South Africa - and the pressure it places on nurses who remain - may be contributing to a high rate of maternal mortality in that country.

\section{AGING}

Elderly people in Cambodia are faced with tremendous disadvantages and have a potentially greater number of and more severe health problems than older people in other parts of Asia or the world.

See page 3

\section{HIV/AIDS}

Can children who lack adult protection and guidance give truly informed consent? 